\title{
Transforming the Lives of Ordinary People in Malawi Through Radio Listening Clubs
}

\section{Peter Mhagama}

\begin{abstract}
This paper examines how radio listening clubs (RLCs) can be used to improve the lives of ordinary people in Malawi especially in rural areas. The paper draws its conclusion from data obtained through focus group discussions (FGDs) with members of RLCs of two community radio stations, namely Nkhotakota and Mzimba. Other data collection techniques employed are semi-structured interviews with station managers of the two radio stations and members of non-governmental organizations (NGOs) working with the RLCs. The paper argues that RLCs can create a platform for ordinary people to share, discuss, and find ways of how they can increase food availability in their homes, alleviate their poverty, empower ordinary people, and enable them to access loans and farm inputs. In that way, RLCs can contribute to the transformation of ordinary people's lives in the rural areas.
\end{abstract}

\section{Keywords}

Community radio, development, livelihoods, ordinary people, radio listening clubs (RLCs)

The paper examines how radio listening clubs (RLCs) can transform the lives of ordinary people in rural areas of Malawi especially in the areas where this research was conducted. A listening club is a "small listening and discussion group that meets regularly to receive a special radio programme, which the members then discuss” (Manyozo 2012: 29). In the RLCs, ordinary people assemble to listen to a radio programme, discuss the content for its merit, and then decide how best to use the information. This paper argues that RLCs have the potential of transforming the lives of ordinary people for the better, because the information they receive, share, and discuss can empower them to make informed decisions and to be knowledgeable. The paper attempts to answer the question, how can RLCs be used to transform the lives of ordinary people in rural areas? The paper gives an overview of RLCs, the motivation behind them, and finally discusses how RLCs can transform the lives of ordinary people. The author uses case studies of two community radio stations namely Nkhotakota and Mzimba in Malawi.

In tracing the origins of RLCs (Lewis and Booth 1989), single out Canada as a place where they were first introduced during the Second World War in 1940, and at that time, they were known as radio forums. India was the second country to start using radio forums in 1949 before they spread to Africa particularly in Ghana between 1964 and 1965 where they aimed at educating adults and stimulating village self-help efforts (Berrigan 1979: 22). Apart from Ghana, RLCs also spread to other African countries

aUniversity of Malawi, Malawi

\section{Correspondent Author:}

Peter Mhagama, University of Malawi-The Polytechnic, P/Bag 303, C, Chichiri, Blantyre 3, Malawi

E-mail: petermhagama@yahoo.co.uk 
such as Malawi in 1966, Tanzania in 1967, and Senegal in 1969. Each country adopted its own model of implementation depending on its development needs (Berrigan 1979). For instance, between 1977 and 1978, Audio Cassette Listening Forums (ACLF), using audio cassette recorders, were used in Tanzania to provide a development programme that enabled women to recognize the importance of their role (Berrigan 1979: 48).

In Malawi, RLCs were introduced in 1966. At that time, they were known as farmers' forum listening groups (Mackie 1971). Malawi gained independence in 1964 and since then, the Malawi Broadcasting Corporation (MBC) radio acted as a communication tool in agricultural and rural development. MBC radio was used in agricultural and rural development to compensate for the many logistical, financial, staffing, and transport constraints in the Ministry of Natural Resources' Extension Service with regards to "teaching Malawi's farmers better agricultural methods" (Mackie 1971: 106). MBC was the only radio station in Malawi during the single party system from 1964 to 1994 when the country adopted a multiparty system of government. The Extension Service model is a “system of 'extending' new technology from the research plots of agricultural universities out to farmers through district extension agents" (White 2009: 13). The introduction of the farmers' forum listening group project in July 1966 in Malawi was praised for its cost-effectiveness which also proved to be an effective rural development communication strategy. This was the case because it increased farmers' knowledge and it also provided a link between farmers and agricultural service providers (Mackie 1971: 108).

For the reason above, community radio stations in Malawi have borrowed a leaf from this format. For instance, Dzimwe was the first community radio station in Malawi which started broadcasting in 1998. "In 1994, Malawian women working in print and electronic media established the Malawi Media
Women Association (MAMWA) that initiated a project called Development Through Radio (DTR), with some female journalists connected with PANOS Institute Southern Africa (PSAF) and the BBC” (Chirwa 2005: 42). MAMWA set up 12 RLCs while the staff at Dzimwe itself established three other clubs bringing the total to 15 (Chirwa 2005: 35). Another community radio station-Nkhotakota, which was established in 2003 also set up 32 RLCs within its area of coverage as support networks. According to Manyozo (2012: 144), listening clubs "facilitated participation of people at all levels to identify appropriate and sustainable policies, programmes, and technologies to implement to reduce poverty and improve livelihoods". It is for this reason that this paper investigates how RLCs can expose marginalized groups of people to various opportunities for the transformation of their lives apart from being support networks.

\section{PARTICIPATORY/“ANOTHER DEVELOPMENT” PARADIGM}

The RLCs are established on the understanding that its members would be involved in participatory radio programme production "based on development discourses" (Manyozo 2012). Therefore, the participatory or "another development" theory was employed in this study to help understand how RLCs operate and how they can transform the lives of ordinary people. "Another development” paradigm has been defined as "need-oriented, endogenous, self-reliant, ecologically sound and based on participatory democracy and structural transformations” (Servaes 1996: 32).

The theory was introduced when the Dag Hammarskjold Foundation released a report in 1975 titled "What Now? Another Development" (Carpentier 2011). According to Servaes (1999: 78-79), the phrase "another development" in the title indicates "the ambition to develop another type of development grounded in the focus on the people's 
basic needs (such as eradication of poverty), self-reliance, ecological sensitivity, sustainability and participation". This pointed to the idea that development that focuses on human freedom and capabilities is more empowering and meaningful and accords individuals more personal freedom than any other notion of development. According to Carpentier (2011: 50), the Dag Hammarskjold Report views the former approaches to development as "reductionist and top-down, and more supportive of transnational capital than development and poverty reduction”. Instead, the report emphasizes another development characterized by a diversity of approaches, like multiplicity, empowerment, and autonomous development approaches. The understanding is that development and social change should "focus on the needs of the lower echelons" of the social system (Carpentier 2011: 50). This is where the issue of grassroots participation came in, both as a means and an end to the process of development. As a means, participation becomes a tool for achieving development, and as an end, participation enhances societal equity, empowerment, transparency and social justice (Carpentier 2011: 48).

\section{MAINSTREAMING PARTICIPATION IN DEVELOPMENT DISCOURSES}

Thus, by the late 1980s, the term participation was mainstreamed in large-scale development programmes. This resulted in most government development programmes scaling up participation, for example, structures such as "Users Committee" at the local level and methods such as "participatory rural appraisal” (PRA) were used to promote such participation in many development projects (Tandon 2008: 289). By early 1990s, many international agencies such as SIDA (Swedish International Development Agency) and USAID (United States Agency for International Development) had mainstreamed participation and empowerment in the development projects that they were implementing worldwide (Tandon 2008: 289).

Here emphasis shifted from the broader levels of participation in developing societies to participation in setting of development projects, where it is aimed at empowering people, capturing the indigenous knowledge, and ensuring the sustainability and efficiency of the interventions (Carpentier 2011: 51).

Thus, participation requires a higher level of people's involvement in the development projects. "Here individuals are active in development programmes and processes, they contribute ideas, take initiatives, articulate their needs and problems and assert their autonomy” (Melkote 1991: 237).

\section{DEVELOPMENT REDEFINED}

Therefore, the inclusion of the term participation in development discourses shifts the emphasis and understanding of development as economic growth to that of development as human freedom and capabilities (Sen 1999). According to Stevenson (1988), the 1980's definition of development included a concept of “development news". Development news is defined as "that which promoted development, everything from literacy and personal hygiene to agricultural practices and family planning” (Stevenson 1988: 13). For Stevenson (1988), development means the outcome of improved well-being such as literacy, hygiene, food availability and having smaller families as a result of information addressing these issues, and community radio stations are established to fulfill such roles. In the absence of these development indicators, ordinary people cannot be said to be free.

According to Sen (1999: 3), development means "a process of expanding the real freedoms that people enjoy”. This means helping people achieve the things that can help them attain the life of value. With this understanding, development is measured by how much freedom ordinary people are able to enjoy as a 
result of the opportunities, one of them being RLCs which can contribute to transformation of their lives.

\section{RLCS-PARTICIPATION AND DEVELOPMENT}

Participatory development projects employ participatory communication in the production of their development messages. Participatory communication is defined as "that type of communication in which all the interlocutors are free and have equal access to the means to express their viewpoints, feelings and experiences" (Bordenave 1994: 43). This is characteristic of what happens in RLCs. Participatory communication reinforces Freire's (1970) strong belief that individuals, no matter who they are, have the capacity and ability to think critically, make decisions, and plan for social change in order to bring about their own social transformation and the transformation of the whole society. In the RLCs, local people can freely share and discuss information to reach a consensus on what they want to do or to be done and how to do it. "Rather than view themselves as somehow deficient or lacking in their ability to effect social change, communities could, through participatory methods (such as RLCs), reassert and reclaim their capacity to transform their daily lives" (Howley 2010: 184). Therefore, RLCs are a local initiative which can transform the lives of marginalised people as this paper argues.

\section{METHODS}

This research was conducted between October 2012 and March 2013. Data were collected using focus group discussions (FGDs), face-to-face interviews, and participant observation. At first, the author conducted face-to-face interviews with the deputy station manager of Nkhotakota Community Radio station in Nkhotakota district. Nkhotakota community radio station was established in 2003. After that, the author conducted participant observation of what happens in RLCs by sitting together with the members of the clubs. He listened to radio programmes at two RLCs and participated in the discussions that members hold after listening to the programmes. He also observed how they conduct their discussions and how they arrive at a decision or consensus. A total of six FGDs were conducted with members of six different RLCs. The same procedure was repeated at Mzimba community radio station in Mzimba district where the author conducted face-to-face interviews with the station manager, and the programmes manager. Then, he also conducted FGDs with the farmers of Chinombotchaya and Njatose Farmers Clubs. Mzimba community radio station does not have RLCs but works with farmers clubs that were established by an NGO (non-governmental organization) called Farmers Voice Radio (FVR) which partnered with community radio stations in Malawi to disseminate agricultural information to farmers. It was established in 2007. Finally, the author conducted a face-to-face interview with the projects manager of FVR. All the observations were recorded in a diary while the FGDs and interviews were recorded and later transcribed. The results are presented below.

\section{REASONS FOR ESTABLISHING RLCS}

According to the deputy station manager of Nkhotakota community radio station, the station has 32 RLCs in its area of coverage (the whole of Nkhotakota district). These RLCs are composed of the chairperson, secretary, treasurer, and members. Each club is supposed to have 25 members but due to large numbers of people in the villages willing to join, the total number of members exceeds 25 in some instances. Membership in these clubs is open to anyone willing to take part on voluntary basis (interview with deputy station manager, Edward Kuwacha, October 2012). 
The deputy station manager further explained that the RLCs which were set up by Nkhotakota community radio station had three major aims, first, as support networks to ensure that there are listeners out there. These listeners give feedback to the radio station on its programming and other issues related to the radio station. This is also a way of ensuring that there is a listening audience out there. Secondly, the clubs aimed to generate income for the radio station. The station sells branded plain papers to RLCs and individuals at a profit. The branded papers are used for writing letters to the radio station. As an income generating activity, the clubs compete among themselves by buying many papers and writing more letters, thereby making more money for the station and making their clubs famous (interview with deputy station manager, Edward Kuwacha, 2012). Finally, some programmes were established with the aim of imparting specific messages targeting specific groups of people in the community. For example, these could be programmes aimed at spreading messages about agriculture, HIV/AIDS (human immunodeficiency virus/acquired immune deficiency syndrome), safe motherhood, or programmes targeting fishermen, and so on. These could be sponsored programmes by NGOs or those produced by the community radio station itself. Therefore, the third reason was to ensure that programmes produced to achieve specific development purposes had an impact on the target audiences. The impact expected could be change in behaviour or adoption of a new farming technique. This means that some specific radio programmes have their own listening clubs whereby members internalize the message contained in the programme and then use it for their own good. The RLCs receive logistical support and training from the community radio station to sustain the clubs, for example, they are given equipment such as recorders for recording their debates and programmes (interview with Edward Kuwacha, 2012).

As Megwa (2007: 53) argued, “Community support and participation are critical to the existence and survival of community-based organizations including community radio stations”. Therefore, formation of RLCs as support networks was a strategic move. It would be almost impossible to broadcast at community level where there is no community support since community radio stations are ostensibly established for them. Establishment of RLCs also proved beneficial to NGOs such as $\mathrm{FVR}^{1}$ which wanted to use community radio to disseminate agricultural messages to farmers.

The opportunity given to club members to deliberate programme content with the aim of enhancing understanding among them "enables literates and illiterates to leap the illiteracy barrier" (Manyozo 2012: 30). Due to high illiteracy levels among listeners, some people find it hard to understand some concepts broadcast on the radio station. According to Held (2006: 237), “Through sharing information and pooling knowledge, public deliberation can transform individuals' understanding and enhance their grasp of complex problems”. To illustrate this point, the agricultural programmes aired on both community radio stations encourage farmers to adopt new farming techniques to improve crop production. Some of the information is too complex for the farmers to understand on their own. For example, they are advised to plant maize, which is a staple food crop in Malawi, at a spacing of 15 centimetres apart using the 1-1 maize planting system to maximize production. This is contrary to the traditional practice of planting three maize seeds per station at a spacing of 30 centimetres. The ridges have to be 25 centimetres apart. Within their clubs, those who are literates demonstrate to the others how to achieve the prescribed measurements by using sticks. Other modern farming practices include conservation agriculture, irrigation farming, and applying manure in the garden for those who cannot afford fertilizers. Those who are not members of any club may not know this and may end up doing things the wrong 
way. One farmer explained that:

Individually you can hear on the radio that to grow maize using the sasakawa type of farming, you have to make your ridges at a spacing of 25 centimeters apart but without knowing what it really means. However, in our club, we do have some members who can demonstrate using measuring instruments such as sticks. Sometimes we invite our agricultural advisors to explain to us as a group. Therefore, when we go to our farms, we know exactly what to do with the measurements. On the other hand, non-club members have problems with such measurements. (FGD, Kashati Farmers Listening Club, November 3, 2012)

This signifies the importance of interpersonal channels of communication in development communication (Rogers 1976). This technique of incorporating interpersonal oral communication in development communication is, according to Howley (2010: 184), "useful for overcoming resistance to development messages that either ignored or were insensitive to local cultural values, forms and practices”. Therefore, RLCs can provide opportunities for explaining and clarifying complex issues to those who find things hard to understand. This can ensure that everyone follows the advice given as prescribed. In that way, club members can become their own and each others' development agents. In participation, it is the sharing of knowledge and "the transformation of the process of learning itself in the service of people's self-development" that is more important and empowering (Connell 1997). Therefore, RLCs can promote community engagement which can enable marginalized people to "have maximum influence, control and ownership over decisions, forces and agencies, which shape their lives and environments" (Manyozo 2012: 16).

\section{HOW RLCS CAN CONTRIBUTE TO SOCIAL TRANSFORMATION OF ORDINARY PEOPLE'S LIVES}

As Banda (2007: 132) has rightly observed, the concept of RLC is "misleading" because it assumes that club members merely listen to the radio programmes. Yet there are many activities that take place apart from listening to the radio programmes. Listening clubs are more of a social event and an arena for the transformation of local groups of people. This research found that there are many ways in which lives of ordinary people can be transformed as a result of participating in RLCs, as explained below.

\section{ENHANCING FOOD AVAILABILITY THROUGH THE PROMOTION OF MODERN FARMING TECHNIQUES}

Members of the RLCs claimed that the adoption of modern farming practices which members are encouraged to adopt has helped to change the way people used to practice farming as explained below:

If I am to compare with previous years, then we have indeed improved because when we talk of development in the village then it depends on agriculture. Messages from the radio have improved the living standards of most of us. Further to these, lessons about farming practices are no longer scarce. (FGD, Kashati Farmers Club, November 3, 2012)

For an ordinary person in the village, development means food availability and sufficiency. As long as food is available at household and community level, then that is an indicator of development. Here it is noted that RLCs can act as a forum for people to receive, share, and discuss development information. In the end, ordinary people can use the information acquired to practice improved methods of farming to maximize production thereby reducing incidences of hunger. In this way, RLCs can expand opportunities for such people to achieve a life they value. This enhances the notion that development is a human issue and not necessarily an economic one (Sen 1999). Farmers are more likely to adopt and implement agricultural messages which can help them to have 
basic needs such as food and avert hunger. As Sen (1999: 208) argued, "It is important to see the production of food as a result of human agency, and to understand the incentives that operate on people's decisions and actions”. In adopting modern methods of farming, ordinary people are moved by the incentive of increased yield that is associated with those techniques. Increased yield leads to freedom as a result of food sufficiency. Food sufficiency leads to the attainment of yet other freedoms such as social and economic freedom which ensue when farmers sell the surplus food to earn money.

\section{HELPING INDIVIDUALS AND THE COMMUNITY TO ALLEVIATE POVERTY}

It has been argued that, "While the community radio movement is worldwide, its resonance is most felt in places where the world's most vulnerable people eke out precarious livelihoods in a bid to escape poverty" (da Costa 2012: 138). Within the RLCs, members support each other to achieve their individual and collective goals of escaping from poverty. In their "bid to escape poverty", the members of RLCs ensure that they are progressing together despite the problems that individual members may face. For example, it was reported that:

We assist each other in the groups. A person cannot stand alone. For instance, if one falls sick, the club members help that person to cultivate in his garden-a thing that cannot happen when you are not in a club. (FGD, Mpamantha Farmers Club, November 4, 2012)

According to Sen (1999: 87), "Poverty must be seen as the deprivation of basic capabilities rather than merely as lowness of incomes”. Because the members of the RLCs have low incomes, they assist one another in cultivating their gardens and by sharing the little resources that they have to ensure that they achieve their goal of alleviating poverty.

Similarly, a study of RLCs in Malawi and Zambia found that "Many members of the clubs viewed themselves as an entity of solidarity, bound together in their desire to extricate themselves from the effects of poverty on their communities" (Banda 2007: 141). This is the main reason why ordinary people join RLCs. To illustrate this point further, one farmer confessed how he was specifically assisted by his club members:

Being in a club is very important. For instance, I did not buy fertilizers this year because I didn't have money, but my fellow club members helped me with some fertilizers and now at least I have maize. If I were not in the club, I was not going to be able to harvest the maize that I have now because I didn't have the fertilizers. (FGD, Mpamantha Farmers Club, November 4, 2012)

It can be argued that RLCs can create support networks for the members. According to Alkire (2010: 25), people are "not only the beneficiaries of development; they are also agents, whose vision, ingenuity and strength are vital to advancing their own and others' well-being”. In the RLCs, the farmers consider themselves to be each others' development agents. For example, it was reported that,

In our meetings, we also make sure that every member knows how to do these things (modern farming techniques) on their own with the help of those members who have understood them better, for example, this practice of growing maize at 25 centimeter apart. (FGD, Kashati Farmers Club, November 3, 2012)

Therefore, it can be argued that RLCs can contribute to the attainment of collective capabilities. Collective capabilities are defined as "The newly generated functioning bundles a person obtains by virtue of his/her engagement in a collectivity that help her/him achieve the life he/she has reason to value" (Ibrahim 2006: 398). The collectivity here is the RLC, and these collective capabilities are achieved through group listening to the radio, discussing the message, and adopting the best practices contained in the message, for example, modern farming practices. This 
can help to bring about social change among those who follow the advice. As a result of the benefits realized by early adopters, the laggards can also be persuaded to join clubs with an aim of realizing the same. One farmer testified that:

I was one of the hard nuts to crack. I did not know that planting one maize seed per station is good and I could laugh at those people who used to follow this method. Now when the advisor came to us together with the chairman of the club, they explained the importance of planting one maize seed per station and they asked me to make manure and plant my maize seeds as advised. I found that it worked very well then I completely changed my mindset and I have finally adopted the use of manure and planting one seed per station. (FGD, Mpamantha Listening Club, November 4, 2012)

It is common knowledge that people always resist change. However, as Megwa (2007: 54) argued, "When an individual, for example, is trained to perform certain functions at a community radio station or learns from listening to community radio programmes, it is generally accepted that this knowledge and skill will be diffused to other members of the community". In the case above, the RLC has helped to persuade those people who resist change to see the importance of adopting modern farming techniques. It has been reported that the number of farmers practicing conservation agriculture in the central region of Malawi where Total Land Care (TLC) promoted the practice in the communities grew from the initial 12 in 2005 to over 30,000 in 2012. Part of this increase can be attributed to RLCs which TLC introduced which helped to influence other farmers to join.

\section{ECONOMIC EMPOWERMENT: EASY ACCESS TO LOANS AND OTHER MATERIAL RESOURCES}

The term empowerment has been described by several scholars in different ways. However, common in all the definitions is the urge for disenfranchised or marginalized people wanting to transform their lives and their community, to control and influence decisions in their environment (Narayan 2002; Nair and White 1993). For example, Butterfoss (2006: 326) defined empowerment as "a multilevel construct that describes a social action process for people to gain mastery over their lives, their organizations, and the lives of their communities”. Therefore, empowerment just like participation is emancipatory. Narayan (2002) identified four key components of empowerment as being access to information, participation, accountability, and local organisational capacity. This section analyzes how RLCs can be used to empower ordinary people economically.

RLCs can transform lives of rural people by giving them an opportunity to access loans, farm inputs, and information easily. Community radio stations are used to link RLCs to different organizations which come to assist members with various aspects of their personal and community development. The farmers, for example, reported that "We are encouraged because in our groups, it is now easy to access loans" (FGD, Kashati Farmers Club, November 3, 2012). Banda (2007) attributed this to the credit worthiness of RLCs to attract external loans to their “organisational” structure. Banda (2007: 143) argued that "the knowledge that the clubs were organized structures, complete with rules and decision-making processes, presented an attractive forum for several development partners and policy-making elites to work with the clubs". This is also the case with the RLCs in the author's research. They act as a platform to help farmers find organizations which assist them with free seeds, fertilizers, and to find markets for their produce. The farmers reported that:

We have other organizations in this village that help us. We have NASFAM (National Smallholder Farmers' Association of Malawi) which assists us with groundnut seeds. NASFAM assists us because we are united and we do our activities as one. (FGD, Mpamantha Farmers Club, November 4, 2012)

When people are already organised in clubs, it becomes easier for NGOs and other organisations to 
mobilise them for a particular development project in the community. These opportunities are not available to community members who are not in clubs. The RLCs are used as collateral when accessing loans, and in that way, they are a form of social capital for the members or farmers. "Social capital is created through citizens' active participation in organizations and groups but is in itself a set of features of social organizations-like trust, norms and networks" (Damasio 2011: 40). Therefore, farmers' participation in RLCs can be one way of ensuring that they get assistance and loans from lending institutions for the sustainability of the livelihoods.

\section{ACCESS TO CASH THROUGH VILLAGE BANKS}

The RLCs are also used as credit cooperatives in form of village banks. What a village bank is and how it is managed by the local people is explained below in the words of the ordinary farmers themselves:

A village bank is about keeping and lending money. After selling our farm produce, we keep our money in this village bank and we meet every Thursday for this village bank... Then we start lending the money to each other to open up small scale businesses to help us look after our families in order for us to reduce our socio-economic problems. If we make profits, we repay the money to the bank. Here we don't have those high interest rates on the money that we borrow from the village bank. If one has a problem with paying school fees, the best solution is to go to the village bank to borrow money and send a child to school and we repay the money at a low interest rate. (FGD, Njatose Farmers Club, November 13, 2012)

The farmers claimed that their socio-economic statuses have improved as a result of accessing loans from the village banks. Ordinary people open small scale businesses through loans obtained from the village bank.

Furthermore, the farmers buy shares in the village bank at an agreed price depending on what the members of the club have agreed on. One farmer explained that: "We heard from the radio that we should be keeping and borrowing money from the village bank and truly we accepted this wholeheartedly. This message was passed through Radio Mzimba” (FGD, Njatose Farmers Club, November 13, 2012). If the money invested in the bank accumulates to a substantial figure, then the farmers are allowed to borrow the money to assist them to open up small scale businesses to help improve their socio-economic status. The money is paid back to the bank at the rate of $1 \%$ which is far much better than the rate charged by commercial banks. The money is supposed to be paid back in three months time from the time of borrowing. At the end of the season, farmers share the dividends and this money is used for the purchase of fertilizers and other farm inputs in preparation for the next growing season.

I thank Radio Mzimba on village banking-keeping and lending money. For example, we are going to share the money that we kept with this village bank on November 22 (2012). In the end, we shall be able to purchase fertilizer if our names have been skipped on the list of beneficiaries of the farm input subsidy programme. (FGD, Njatose Farmers Club, November 13, 2012)

The dividends are shared according to the number of shares one has in the bank. The more shares one has, the more he/she gets.

In addition to the subsidised fertilizer, we use the village banks whereby people share the money at the end of the season. This money is used to buy fertilizer to be applied into our fields. People buy fertilizers in their groups. The secret is that the person who contributes more to the bank will get more money when sharing the money kept at the bank at the end of the season. (FGD, Njatose Farmers Club, November 13, 2012)

Therefore, RLCs can help to transform the lives of rural people by creating opportunities for them to meet their economic goals, for example, by accessing loans 
to establish small scale businesses. This can help to ease people's financial constraints in times of need such as funerals, when sending children to school, and buying farm inputs. Community radio stations attract well wishers and NGOs to work with local people in RLCs and empower them with skills with which to improve their living standards. This is how, "Community participation is related to empowerment since, by participating, members expand their power from within to create needed changes" (Butterfoss 2006: 327).

\section{CONCLUSIONS}

In conclusion, this paper has discussed the concept of RLCs, and how it can be used to transform the lives of ordinary people who form membership of the clubs. The discussion has shown that RLCs can create a platform for ordinary people to increase food availability in their homes, alleviate their poverty, empower marginalized people, and enable them to access loans and farm inputs. In that way, RLCs have the potential to contribute to the transformation of ordinary people's lives in the rural areas. They can be used to raise ordinary people's awareness to existing problems and influencing them to do something about their situation. RLCs can also help ordinary people to achieve a life of value and building their agency. The people's claims about the positive changes that have taken place in the study areas which they attribute to the two radio stations and RLCs are evidence of increased agency. By providing a forum for the discussion of issues affecting ordinary people, RLCs can help to raise awareness to those problems thereby enabling the people to do something about them. In the final analysis, it can be argued that RLCs can provide a platform for ease of access to information and other resources which can contribute to the transformation of the lives of marginalized people. The RLCs are informal institutions which if formalized together with some of the activities such as village banks, they can help to further improve the livelihoods of many rural people thereby contributing to development of rural communities.

\section{Notes}

1. In Malawi, FVR is a consortium made up of the Ministry of Agriculture, Irrigation and Water Development (MoAIWD); Bunda College of Agriculture, a former constituent college of the University of Malawi; Centre for Alternatives for Victimized Women and Children (CAVWOC); Creative Centre for Community Mobilization (CRECCOM); Farm Radio Malawi; Malawi Broadcasting Corporation (MBC); and all community radio stations in Malawi with funding from the Bill and Melinda Gates Foundation of the USA (http://www.creccom.org/project.php?project=44).

2. This information was obtained from a blog available on the International Maize and Wheat Improvement Center website: http://blog.cimmyt.org/?tag=total-land-care.

\section{References}

Alkire, S. 2010. "Human Development: Definitions, Critiques, and Related Concepts.” Background paper for the 2010 Human Development Report. OPHI Working Paper No. 36. Oxford: OPHI.

Banda, F. 2007. "Radio Listening Clubs in Malawi and Zambia: Towards a Participatory Model of Broadcasting." Communicare 26(1):130-148.

Berrigan, F. J. 1979. Community Communications: The Role of Community Media in Development. Paris: UNESCO.

Bordenave, J. D. 1994. "Participative Communication as a Part of Building the Participative Society." Pp. 35-48 in Participatory Communication: Working for Change and Development, edited by S. A. White. Beverly Hills: Sage.

Butterfoss, F. D. 2006. "Process Evaluation for Community Participation.” Annual Review Public Health 27:323-340. Retrieved February 28, 2012 (http://www.annual reviews.org).

Carpentier, N. 2011. Media and Participation: A Site of Ideological-Democratic Struggle. Bristol: Intellect.

Chirwa, W. C. 2005. "Community Broadcasting in Malawi: Which Way Forward.” A country assessment paper prepared for AMARC. Chancellor College: University of Malawi.

Connell, D. 1997. "Participatory Development: An Approach Sensitive to Class and Gender." Development in Practice 7(3):248-259.

da Costa, P. 2012. “The Growing Pains of Community Radio in 
Africa: Emerging Lessons Towards Sustainability.” Nordicom Review 33(Special Issue):135-148.

Damasio, M. J. 2011. "Social Capital: Between Interaction and Participation.” Communication Management Quarterly 21:37-60.

Freire, P. 1970. Pedagogy of the Oppressed. New York: Seabury Press.

Held, D. 2006. Models of Democracy. 3rd ed. Cambridge: Polity Press.

Howley, K., ed. 2010. Understanding Community Media. Thousand Oaks: Sage.

Ibrahim, S. S. 2006. "From Individual to Collective Capabilities: The Capability Approach as a Conceptual Framework for Self-Help.” Journal of Human Development 7(3):397-416.

Lewis, P. M. and J. Booth. 1989. The Invisible Medium: Public, Commercial and Community Radio. London: MacMillan.

Mackie, W. E. 1971. "Radio Broadcasting in Malawi: A Search for Identity and Service." Unpublished PhD dissertation submitted to the Faculty of the Graduate School of the University of Missouri at Columbia.

Manyozo, L. 2012. People's Radio: Communicating Change Across Africa. Penang: Southbound.

Megwa, E. R. 2007. “Community Radio Stations as Community Technology Centers: An Evaluation of the Development Impact of Technological Hybridization on Stakeholder Communities in South Africa." Journal of Radio Studies 74(1):49-66.

Melkote, S. R. 1991. Communication for Development in the Third World: Theory and Practice for Empowerment. London: Sage.

Nair, K. S. and S. White, eds. 1993. Perspectives on
Development Communication. New Delhi: SAGE Publications.

Narayan, D., ed. 2002. Empowerment and Poverty Reduction: A Sourcebook. Washington, D.C.: The International Bank for Reconstruction and Development.

Rogers, E., ed. 1976. Communication and Development. Beverly Hills: Sage Publications.

Sen, A. 1999. Development as Freedom. Oxford: Oxford University Press.

Servaes, J. 1996. "Participatory Communication (Research) From a Freirian Perspective.” Africa Media Review 10(1):92-114.

- 1999. Communication for Development: One World, Multiple Cultures. Cresskill, NJ: Hampton Press.

Stevenson, R. L. 1988. Communication, Development, and the Third World. New York: Longman.

Tandon, R. 2008. "Participation, Citizenship and Democracy: Reflections on 25 Years' of PRIA.” Community Development Journal 43(3):284-296.

White, R. A. 2009. "Grassroots, Participatory Communication in Africa: 10 Major Lines of Research.” Communication Research Trends 28(1):3-27.

\section{Bio}

Peter Mhagama, Ph.D. in media and communication studies obtained from the University of Leicester in the United Kingdom in 2015, senior lecturer, the University of Malawi-The Polytechnic; research fields: community media and development, communication for development, citizen participation and empowerment, political economy of communication, globalisation, and media freedom. 